\title{
Late-glacial (Allerød) Coleoptera from Joggins, Lantz and Blomidon, central Nova Scotia, Canada
}

\author{
Randall F. Miller \\ Steinhammer Palaeontology Laboratory, New Brunswick Museum, \\ 277 Douglas Avenue, Saint John, New Brunswick E2K 1E5, Canada
}

Date Received April 14, 1997

Date Accepted August 4, 1997

\begin{abstract}
Three late-glacial sites in central Nova Scotia, Canada, have produced small Coleoptera assemblages that add to the palaeoenvironmental interpretation during the interval 11,800 to 10,800 years B.P. in the Maritimes region. During this time, beetle assemblages are boreal in nature, in contrast to older sites which contain tundra to tree-line species and later, Younger Dryas age sites, containing northern boreo-montane species. Palaeoentomological interpretations from buried organic sites near Joggins, Lantz and Blomidon are consistent with palynological results from the region and support evidence derived from lake sediments for regional steep climatic gradients during the late-glacial period in the Maritimes.

Trois emplacements tardiglaciaires du centre de la Nouvelle-Écosse, au Canada, ont produit des assemblages de petits coléoptères qui ajoutent à l'interprétation du contexte paléoenvironnemental existant pendant l'intervalle de 11800 à 10800 ans BP dans la région des Maritimes. Au cours de cette période, les assemblages de coléoptères présents étaient de nature boréale, par contraste avec les emplacements plus anciens abritant des végétaux variant de la toundra à la limite de végétation des arbres, ainsi qu'avec les sites plus récents de l'époque des dryades ultérieurs renfermant des espèces boréales subalpines septentrionales. Les interprétations paléoentomologiques des emplacements organiques en fouis près de Joggins, Lantz et Blomidon correspondent aux constatations palynologiques de la région et appuient les indications tirées des sédiments lacustres témoignant de gradients climatiques régionaux élevés pendant la période tardiglaciaire dans les Maritimes.
\end{abstract}

[Traduit par la rédaction]

\section{INTRODUCTION}

Studies of fossil beetles from late-glacial buried organic deposits in Atlantic Canada (Miller and Morgan, 1991; Miller, $1995,1996,1997$ a, 1997b) have suggested a three phase framework for understanding changes in Coleoptera assemblages from about 12,600 to 10,600 years B.P. This paper presents details of the Coleoptera fauna from three late-glacial sites of Allerød age from central, mainland Nova Scotia in eastern Canada (Fig. 1). Fossil representation is relatively poor in these sites. However, in the context of an overall picture of late-glacial beetle assemblages in the region, they provide valuable information for the period 11,800 years B.P. to the onset of the Younger Dryas around 10,800 years B.P.

Over the past decade a number of papers have discussed the late-glacial environment of Atlantic Canada. Mott et al. (1986a), Stea and Mott (1989), Mott and Stea (1993) and Mott (1994) summarized information gathered from a number of buried organic sites in New Brunswick and Nova Scotia and provided stratigraphic interpretation, radiocarbon chronology and pollen records that have been used to piece together a picture of late-glacial environments from about 14,000 to 10,000 years B.P. The work has resulted in a detailed analysis of deglaciated environments and evidence for active glaciers of Younger Dryas age in Nova Scotia. Additional work has provided detail of the timing of the
Younger Dryas in Atlantic Canada (Mayle et al., 1993a) and about late-glacial vegetation patterns (Mayle et al., 1993b; Mayle and Cwynar, 1995). Published studies have also included chironomid and diatom analyses (Walker et al., 1991; Wilson et al., 1993).

\section{Methods}

Samples of peat and organic-rich sediment were taken in thicknesses of 5 to $10 \mathrm{~cm}$ and submitted to standard palaeoentomological analysis using a kerosene floatation technique to isolate chitinous fragments (Elias, 1994). Untreated samples and processed residues were retained for other possible analyses. Identified Coleoptera specimens were mounted on micropalaeontology slides or stored in alcohol and were catalogued and counted. All specimens and samples, including residues, are stored in the palaeontology collections of the New Brunswick Museum.

\section{Site DESCRIPTIONS AND PALAEOENTOLOMOLOGY}

$$
\text { Joggins }
$$

The site is located north of Joggins, Nova Scotia on the road to Lower Cove $\left(45^{\circ} 42.85^{\prime} \mathrm{N}, 64^{\circ} 26.10^{\prime} \mathrm{W}\right.$; Fig. 1). It was described by Mott (1985) and in radiocarbon report notes 


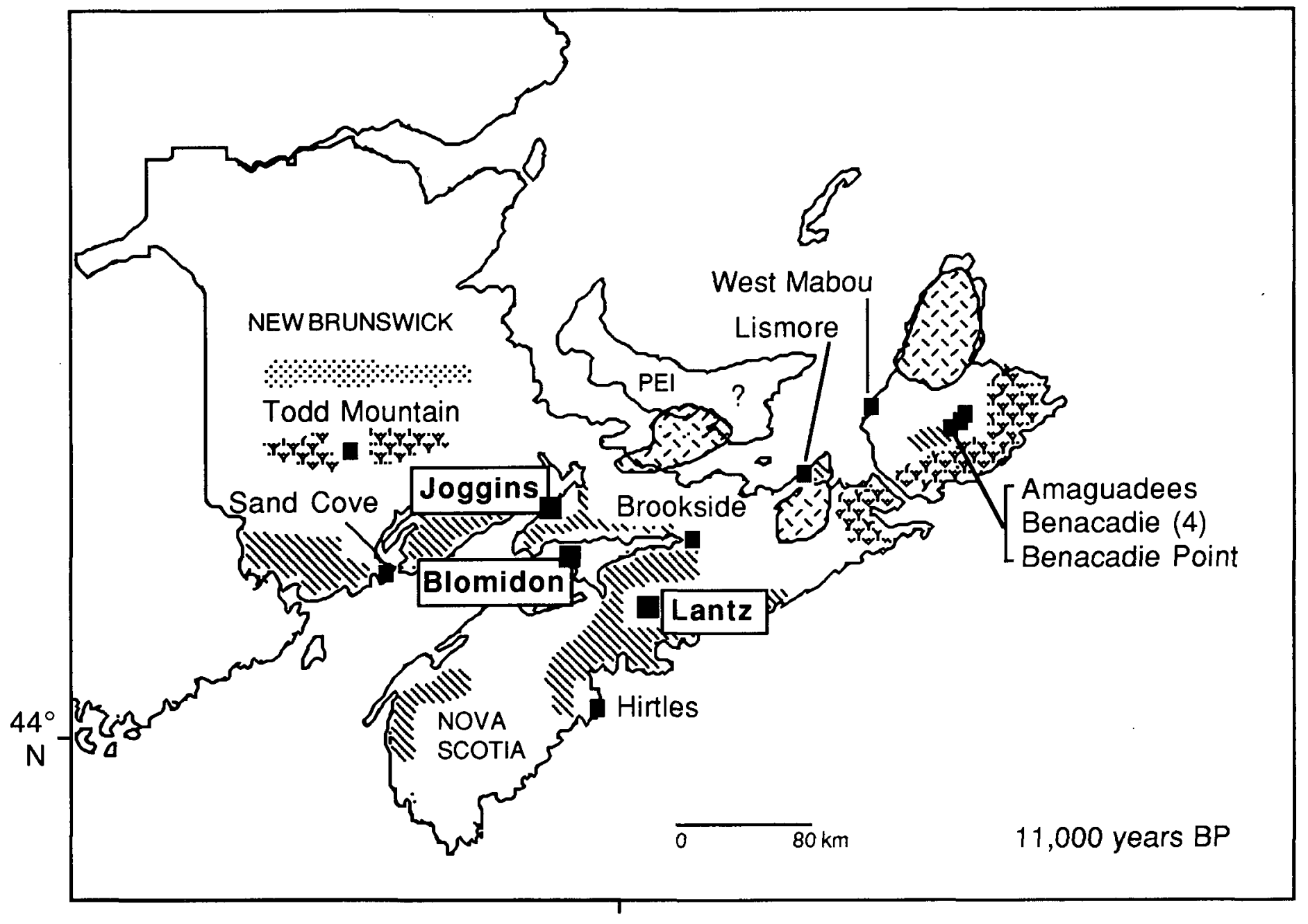

$64^{\circ} \mathrm{W}$

$\begin{array}{ll} & \text { Glacier Ice } \\ \text { his } & \text { serb tundra } \\ & \text { open woodland }\end{array}$

Fig. 1. Approximate ice positions and nature of vegetation in relation to late-glacial buried organic sites at Joggins, Lantz and Blomidon, Nova Scotia, and other late-glacial sites in Nova Scotia and New Brunswick, Canada at about 11,000 years B.P.

(McNeely, 1989). The site was originally described as a 10 to $15 \mathrm{~cm}$ thick, compact fibrous peat, overlying $50 \mathrm{~cm}$ of reddish brown diamicton, and more than $2 \mathrm{~m}$ of yellow sand with red silt lenses (Fig. 2). The peat was overlain by 30 to $40 \mathrm{~cm}$ of sand of undetermined origin (Mott et al., 1986a; Stea and Mott, 1989). A bulk sample of compressed fibrous peat produced a radiocarbon date of $11,400 \pm 100$ years B.P. (GSC-3550). Two additional samples from upper and lower, $2 \mathrm{~cm}$ increments yielded ages of $11,100 \pm 120$ years B.P. (GSC-3924) and 11,800 \pm 110 years B.P. (GSC-3915) respectively. Since the original description, the cliff has eroded back, leaving a very thin silty peat bed exposed at the top of the bluff under overhanging grass. Up to $16 \mathrm{~cm}$ of silty peat overlies $10 \mathrm{~cm}$ of reddish green sand, which in turn rests on top of a reddish diamicton.
Pollen analysis (R. Mott in McNeely, 1989) suggested a wet, sedge covered area, surrounded by shrub and herb tundra-like vegetation, dominated by willow (Salix) and buffaloberry (Shepherdia canadensis). Mott interpreted the older date of 11,800 years B.P. to mark the beginning of organic accumulation as the climate warmed following deglaciation and the younger date of 11,100 years B.P. to represent the time of cessation of organic deposition caused by severe climatic deterioration that decimated the vegetation. The younger date of 11,100 years B.P. is 300 years before the onset of the Younger Dryas in the Maritimes (Mayle et al., 1993a) and may likely date an erosional surface in the peat.

A small beetle assemblage was isolated from a bulk peat sample weighing $10.3 \mathrm{~kg}$ and equivalent to the period 11,800 

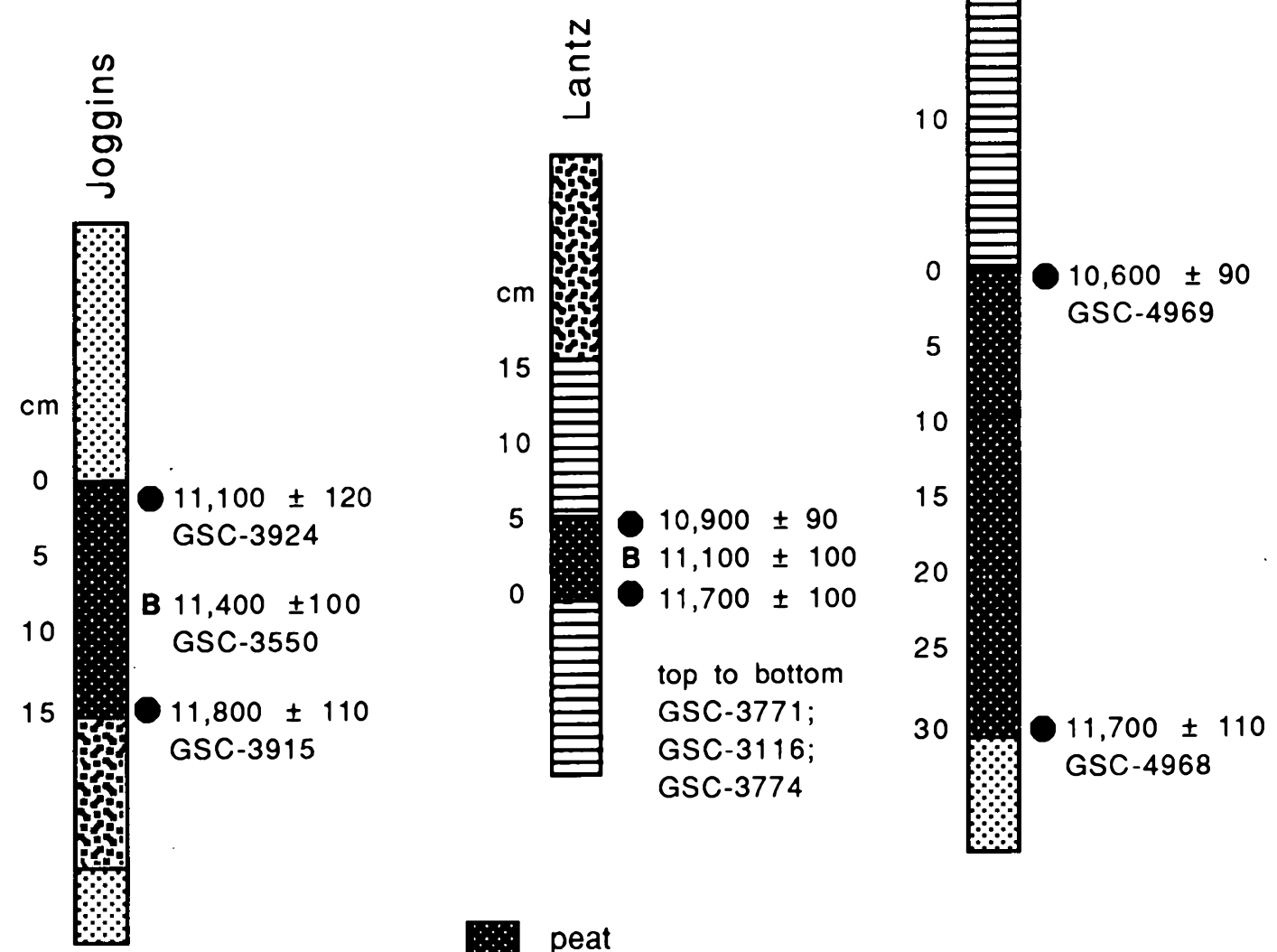

peat

clay

Fia diamicton, till

sand/gravel

- C-14 date $\mathbf{B}=$ Bulk Sample

Fig. 2. Stratigraphy and radiocarbon chronology of late-glacial buried organic sites of Allerød age containing fossil Coleoptera at Joggins, Lantz and Blomidon, Nova Scotia, Canada.

to 11,100 years B.P. Clay above the peat contained no beetles and silts below the peat yielded few specimens. In all about $22 \mathrm{~kg}$ of material was examined. Although reworking of fossils is a possibility no obvious evidence was observed. The site contained the ground beetles Bembidion and cf. Agonum, an aquatic beetle, Helophorus cf. lacustris/auricollis, a chrysomelid, Donacia/Plateumaris, staphylinids including Olophrum cf. rotundicolle and numerous Stenus spp., a byrrhid, Cytilus cf. alternatus, a weevil, and two scolytid (bark) beetles. The scolytids are notable in that their numbers, compared to the relatively sparse fauna, are higher than what has been encountered in other Nova Scotia sites.
At least five specimens of Phloeotribus piceae and eight Polygraphus rufipennis were recovered from this site. Phloeotribus piceae inhabits conifer trees of the genus Picea spp., rarely Abies spp. and Larix spp. It is a widely distributed, transcontinental beetle whose distribution follows the boreal forest region from Manitoba to Quebec and the northeastern United States (Bright, 1976). Polygraphus rufipennis inhabits all conifers in its range. Its distribution is transcontinental in Canada and includes the eastern United States, south to North Carolina and Tennessee, western United States south to Oregon and New Mexico (Bright, 1976). 
The few species that can be identified are common inhabitants of the modern boreal forest in Canada and have been found in sites of similar age in Nova Scotia (Miller and Morgan, 1991; Miller, 1995, 1996, 1997a).

\section{Lantz}

The Lantz site is located in central Nova Scotia in the clay quarry of L.E. Shaw Ltd. $\left(44^{\circ} 58^{\prime} 40^{\prime \prime N}, 4^{\circ} 29^{\prime} 10^{\prime \prime} \mathrm{W}\right.$; Fig. 1). The peat bed, up to $40 \mathrm{~cm}$ thick, overlies a sand unit and a lower massive to laminated clay unit. Up to 15 $\mathrm{cm}$ of grey silty sand overlies the peat (Fig. 2). A reddish, blocky, clay-rich diamicton covers the organic unit (Mott $e t$ al., 1986a; Stea and Mott, 1989; McNeely and McCuaig, 1991; Mott and Stea, 1993). A bulk sample of the peat was dated at $11,100 \pm 100$ years B.P. (GSC-3116). One centimetre increments from the top and bottom of the peat horizon have been dated at 10,900 \pm 90 years B.P. (GSC-3771) and 11,700 \pm 100 years B.P. (GSC-3774) respectively. Wood from sandy clay in the upper sand unit produced a date of $9690 \pm 110$ years B.P. (GSC-4042). A calcareous concentration in lower clay unit yielded a date of $11,310 \pm 125$ years B.P. (Q.C.-1411).

Pollen analysis (Stea and Mott, 1989; Mott and Stea, 1993) suggested an abundance of shrubs and herbs dominated the site at 11,700 years B.P., but that spruce trees invaded the surrounding area soon after, to form open woodlands with interspersed low shrubs and herbs. An abrupt change occurred at about 10,900 years B.P., causing a decline in spruce and an increase in shrub birch, other shrubs and herbs.

An assessment of the Lantz site indicates a Coleoptera fauna (Table 1) dominated by aquatic or semi-aquatic beetles such as the chrysomelid Donacia/Plateumaris and Helophorus, Colymbetes and Hydraena. Staphylinids, such as Olophrum consimile, Olophrum rotundicolle and Stenus are riparian species. Olophrum consimile can be found in deciduous leaf litter (especially Alnus and Salix) along the margins of streams, ponds or lakes. They may also be taken from clumps of Carex. $O$. consimile has a transcontinental distribution that generally follows the boreal forest, with southern extensions along the western mountains (Campbell, 1983). Bark beetles, Phloeotribus piceae and Polygraphus rufipennis, indicate the presence of trees, consistent with palynological interpretations from Lantz. Although reworking of fossils is a possibility no obvious evidence was observed.

\section{Blomidon}

The site is located on the Blomidon Peninsula, north-

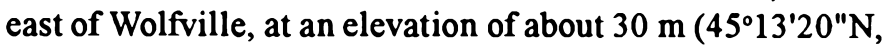
$64^{\circ} 20^{\prime} 30^{\prime \prime} \mathrm{W}$; Fig. 1). At the base of the section a reddish silty till is overlain by a grey to red silty clay (Fig. 2). Peat overlies clay and is, in turn, overlain by a thin clay layer, then 1 to $2 \mathrm{~m}$ of sand (Stea et al., 1992; Mott and Stea, 1993). Two radiocarbon dates were obtained from the 35 $\mathrm{cm}$ thick layer of compressed peat. The basal $3 \mathrm{~cm}$ of peat
Table 1. Coleoptera from the late-glacial Lantz Site, Nova Scotia, Canada.

level 12 bulk*

CARABIDAE**

cf. Bembidion sp.

Blethisa cf. B. quadricollis Haldeman

cf. Blethisa sp.

cf. Stereocerus haematopus (Dejean)

gen. indet.

DYTISCIDAE

Colymbetes sp.

Deronectes sp.

Rhantus sp.

Hydroporus sp.

gen. indet.

HYDROPHILIDAE

Enochrus/Cymbiodyta

Helophorus sp.

Helophorus sp A

Helophorus sp B

gen. indet.

$\begin{array}{lll}1 & 2 & 4\end{array}$

1

1 1

HYDRAENIDAE

Hydraena sp.

$\begin{array}{lll}12 & 0 & 14\end{array}$

$12 \quad 14$

STAPHYLINIDAE

Gymnusa sp.

Olophrum consimile (Gyllenhal)

Olophrum rotundicolle (C.R. Sahlberg)

Olophrum spp.

Omaliinae

Stenus spp.

Aleocharinae

$\begin{array}{lll}25 & 9 & 48\end{array}$

1

$\begin{array}{lll}1 & 1 & 2\end{array}$

12

17

1

SCARABAEIDAE

gen. indet.

1001

CHRYSOMELIDAE

11

Donacia /Plateumaris

$\begin{array}{lll}7 & 1 & 37\end{array}$

$\begin{array}{lll}7 & 1 & 37\end{array}$

ELATERIDAE

gen. indet.

$\begin{array}{lll}\mathbf{0} & \mathbf{2} & \mathbf{0}\end{array}$

SCOLYTIDAE

Phloeotribus piceae Swaine

Polygraphus rufipennis (Kirby)

gen. indet.

${ }^{*} \mathrm{~cm}$ levels $1=0-5 ; 2=5-10 ; 3=$ bulk

**total number of individuals for each Family 
produced a date of $11,700 \pm 110$ years B.P. (GSC-4968) and the top $2 \mathrm{~cm}$ dated at $10,600 \pm 90$ years B.P. (GSC-4969). The origin of a sand body overlying the peat is somewhat problematic, although it has been interpreted as ponded sediment.

Pollen analysis (Stea et al., 1992; Mott and Stea, 1993) indicates a sequence of herb and shrub tundra-like conditions to open spruce woodlands, followed by a reversion to shrub tundra conditions, presumably during the Younger Dryas.

A total of $77 \mathrm{~kg}$ was obtained from peat and clay units at Blomidon. Organic material occurs on both sides of the road. Although reworking of fossils is a possibility no obvious evidence was observed. Most Coleoptera samples were taken from the southwest side of the road opposite the location sampled for pollen and radiocarbon dating (Tables 2 , 3). The beetle fauna throughout the sampled levels consisted largely of Staphylinidae from the genera Stenus and Olophrum. Micropeplus laticollis has been collected from soil, in spruce duff, also from red squirrel midden and nests of Canada Jay. Its distribution is transcontinental boreal from Alaska south to Colorado and east to Quebec and New Hampshire (Campbell, 1963).

A small carabid assemblage includes Chlaenius niger, a very hygrophilous species found in swamps and at the edge of pools where the vegetation is rich but incoherent. Its distribution is almost transamerican, west to Washington State but not reaching the Pacific coast and in the east south to Texas, Florida and Cuba (Lindroth, 1969). Elaphrus lapponicus is less strictly riparian than other Elaphrus. It is very hygrophilous and depends on cold water, but often occurs around wells and trickles with low vegetation and moss. It rarely ascends above the timber limit and is not a true inhabitant of the tundra. In Canada it is found from Labrador, west to Yukon, and in Alaska (Goulet, 1983).

Aquatic beetles are from both the Dytiscidae and Hydrophilidae, including Helophorus, Rhantus and Hydrobius. Bark beetles, of the family Scolytidae are represented by Phloeotribus piceae and Polygraphus rufipennis.

\section{SUMmaRy OF THE PALAEOENVIRONMENT}

Between 12,000 and 11,000 years B.P. ice in Nova Scotia (Fig. 1) retreated to local ice caps in the highland regions (Stea and Mott, 1989). Pollen profiles at Lantz and Blomidon indicate an amelioration of climate that resulted in tundra vegetation giving way to an open spruce woodland. The beetle assemblages described from these sites are similar to each other and contain species whose modern distribution are transcontinental and boreal in nature. Perhaps most interesting is that during this time interval bark beetles have been recovered from Blomidon, Joggins, and Lantz discussed here as well as Lismore (Miller and Morgan, 1991), Hirtles (Miller, 1995) and Benacadie Point (Miller, 1997a). At some sites the distribution of bark beetles corresponds well with the distribution of open woodland/boreal forest suggested by pollen analysis (Stea and Mott, 1989; Mayle and Cwynar, 1995). However, Coleoptera evidence at Joggins and Lismore (Miller and Morgan, 1991) and Benacadie Point on Cape Breton
Table 2. Coleoptera from the late-glacial Blomidon Site, Nova Scotia, Canada, south section.

\begin{tabular}{|c|c|c|c|c|c|c|}
\hline TAXA & 1 & 2 & 3 & 4 & 5 & $6^{*}$ \\
\hline CARABIDAE** & 3 & 1 & 2 & 4 & 3 & 5 \\
\hline $\begin{array}{l}\text { cf. Agonum sp. } 1 \\
\text { cf. Agonum sp } 2\end{array}$ & & & & & 1 & \\
\hline $\begin{array}{l}\text { cf. Agonum sp. } 2 \\
\text { Bembidion of. B. petrosum Gebler }\end{array}$ & & & 1 & 2 & & 1 \\
\hline & 1 & & & & & \\
\hline Dyschirius integer gp. & & & & 1 & 1 & 1 \\
\hline Elaphrus cf. E. clairvillei Kirby & & 1 & & & & \\
\hline cf. Patrobus & 2 & & & & & \\
\hline gen. indet. & & & 1 & 1 & 1 & 3 \\
\hline HALIPLIDAE & $\mathbf{0}$ & $\mathbf{0}$ & 1 & $\mathbf{0}$ & $\mathbf{0}$ & $\mathbf{0}$ \\
\hline Haliplus sp. & & & 1 & & & \\
\hline DYTISCIDAE & 2 & 1 & 1 & $\mathbf{0}$ & 1 & 1 \\
\hline Colymbetes sp. & & & & & & 1 \\
\hline gen. indet. & 2 & 1 & 1 & & 1 & \\
\hline HYDROPHILIDAE & 2 & 8 & 5 & 7 & 4 & 3 \\
\hline Helophorus sp. A & 1 & & & & & \\
\hline Helophorus sp. B & & & & & & 1 \\
\hline Hydrobius melaenus (Germar) & & & & & 1 & 1 \\
\hline cf. Enochrus / Cymbiodyta & 1 & 6 & & & & \\
\hline gen. indet. & & 2 & 5 & 7 & 3 & 1 \\
\hline HYDRAENIDAE & 3 & 10 & $\mathbf{0}$ & 1 & 6 & 1 \\
\hline Hydraena sp. & 2 & 9 & & 1 & 6 & 1 \\
\hline Ochthebius sp. & 1 & 1 & & & & \\
\hline MICROPEPLIDAE & $\mathbf{0}$ & 0 & 1 & $\mathbf{0}$ & $\mathbf{0}$ & $\mathbf{0}$ \\
\hline Micropeplus laticollis Mäklin & & & 1 & & & \\
\hline STAPHYLINIDAE & 7 & 9 & 41 & 14 & 53 & 39 \\
\hline Acidota quadrata (Zetterstedt) & & & & & & 1 \\
\hline Eucnecosum tenue / brunnescens & & & & & & 2 \\
\hline cf. Eucnecosum & 1 & 1 & & & & \\
\hline Gymnusa sp. & 1 & & & & 1 & \\
\hline Lathrobium cf. L. nigrum LeConte & & & 1 & 1 & & \\
\hline cf. Lathrobium sp. & & & 2 & & & 2 \\
\hline Olophrum consimile (Gyllenhal) & & & 1 & & 3 & 5 \\
\hline Olophrum cf. $O$. consimile (Gyllenhal) & 1 & 1 & & 1 & & \\
\hline Olophrum rotundicolle (C.R. Sahlberg) & 3 & 4 & 5 & 5 & 5 & 1 \\
\hline Olophrum spp. & & & 7 & 5 & 11 & 6 \\
\hline Omaliinae & & & & 1 & 1 & 7 \\
\hline cf. Philonthus / Quedius & & 1 & & 1 & 8 & \\
\hline Stenus nr. S.dolosus Casey & 1 & & & & & \\
\hline $\begin{array}{l}\text { Stenus spp. } \\
\text { Aleocharinae }\end{array}$ & & 2 & 25 & & 24 & $\begin{array}{r}13 \\
2\end{array}$ \\
\hline $\begin{array}{l}\text { SCARABAEIDAE } \\
\text { genera indet. }\end{array}$ & $\mathbf{0}$ & $\mathbf{0}$ & $\begin{array}{l}1 \\
1\end{array}$ & $\mathbf{0}$ & $\mathbf{0}$ & $\mathbf{0}$ \\
\hline BYRRHIDAE & $\mathbf{0}$ & 1 & 1 & $\mathbf{0}$ & $\mathbf{0}$ & $\mathbf{0}$ \\
\hline cf. Cytilus alternatus (Say) & & 1 & 1 & & & \\
\hline CHRYSOMELIDAE & 12 & 10 & 30 & 20 & 19 & 6 \\
\hline Donacia / Plateumaris sp. & 12 & 10 & 30 & 20 & 19 & 6 \\
\hline CURCULIONIDAE & 1 & $\mathbf{0}$ & 1 & $\mathbf{0}$ & 1 & 2 \\
\hline $\begin{array}{l}\text { gen. indet. A } \\
\text { gen. indet. B }\end{array}$ & & & & & & $\begin{array}{l}1 \\
1\end{array}$ \\
\hline gen. indet. & 1 & & 1 & & 1 & \\
\hline SCOLYTIDAE & $\mathbf{0}$ & $\mathbf{0}$ & 1 & 1 & 3 & 4 \\
\hline Carphoborus sp. & & & 1 & & & \\
\hline Phloeotribus piceae Swaine & & & & & & 2 \\
\hline cf. Phloeotribus piceae Swaine & & & & 1 & 1 & \\
\hline cf. Polygraphus rufipennis (Kirby) & & & & & 1 & 1 \\
\hline gen. indet. & & & & & 1 & 1 \\
\hline
\end{tabular}

"cm levels $1=25-30 ; 2=20-25 ; 3=15-20 ; 4=10-15 ; 5=5-10 ; 6=0-5$ section sampled from top down, $0-5 \mathrm{~cm}=$ top of peat - "total number of individuals for each Family 
Table 3. Coleoptera from the late-glacial Blomidon Site, Nova Scotia, Canada, north section.

$\begin{array}{lllllll}\text { Taxa } & \text { level } & 1 & 2 & 3 & 4^{*}\end{array}$

\begin{tabular}{|c|c|c|c|c|}
\hline CARABIDAE** & 4 & 1 & $\mathbf{0}$ & 1 \\
\hline Chlaenius niger Randall & 1 & & & \\
\hline Dyschirius sp. & 2 & & & \\
\hline Elaphrus cf. E. lapponicus Gyllenhal & 1 & & & \\
\hline $\begin{array}{l}\text { Elaphrus sp. } \\
\text { gen. indet. }\end{array}$ & & 1 & & 1 \\
\hline STAPHYLINIDAE & 3 & 2 & 26 & 10 \\
\hline Acidota quadrata (Zetterstedt) & & & 1 & \\
\hline Eucnecosum tenue / brunnescens & & & 5 & 2 \\
\hline Olophrum consimile (Gyllenhal) & 1 & & & \\
\hline Olophrum rotundicolle (C.R. Sahlberg) & 1 & & 8 & $\varepsilon$ \\
\hline Olophrum sp. & & 1 & & \\
\hline $\begin{array}{l}\text { Gymnusa sp. } \\
\text { cf. Lathrobium }\end{array}$ & 1 & & 1 & \\
\hline Stenus sp. & & 1 & 5 & \\
\hline Aleocharinae & & & 6 & \\
\hline
\end{tabular}

${ }^{*} \mathrm{~cm}$ level $1=5-15 ; 2=0-5 ; 3=0-10$ above peat; $4=10-25$ above peat section sampled from top down, $0-5 \mathrm{~cm}=$ top of peat

${ }^{* *}$ total number of individuals for each Family

Island (Miller, 1997a) indicates trees may have been more widespread than palynological evidence suggests. Bark beetles such as Phloeotribus piceae and Polygraphus rufipennis are found under the bark of spruce or spruce and fir respectively. Compared with southern Ontario, where open ground to boreal conditions, including the presence of bark beetles, seems to have been established by 13,000 to 12,500 years B.P. (Morgan et al., 1984; Schwert et al., 1985), colder conditions persisted in parts of Nova Scotia and New Brunswick to about 11,800 years B.P.

\section{Discussion}

The Coleoptera recovered from late-glacial sites in Nova Scotia and New Brunswick, illustrate three recognizable phases based upon the presence of one or more species (Miller, 1996, 1997a, 1997b). The periods can be divided into (1) a tundra to tree-line assemblage older than about 11,800 years B.P., (2) a boreal assemblage from 11,800 to 10,800 years B.P., and (3) a northern boreo-montane assemblage younger than 10,800 years B.P. Mean July temperatures for these assemblages are probably in the range of $(1)<9$ to $12^{\circ} \mathrm{C},(2) 14$ to $18^{\circ} \mathrm{C}$, and (3) 12 to $15^{\circ} \mathrm{C}$ respectively.

Coleoptera at Joggins, Lantz and Blomidon are discussed in relation to the overall context of late glacial beetles in the Maritimes. Although small, the composition of the assemblages at Joggins, Lantz and Blomidon is similar to contemporary Nova Scotia sites in the upper part of Hirtles (Miller, 1995), at Lismore (Miller and Morgan, 1991), Campbell
(Miller, 1996), Brookside (Mott et al., 1986b), Benacadie Point, and the middle of Benacadie (4) and Amaguadees (Miller, 1997a). All these assemblages belong to phase 2, typical of a wide range of the modern boreal forest. The exception to the sites from this time interval is Todd Mountain (11,500 years B.P.) in central New Brunswick where the beetle assemblage contains tundra to tree-line species (Miller, 1992). The species list at Todd Mountain includes some of the more widely ranging boreal beetles, such as Acidota quadrata and Olophrum rotundicolle found at other sites. However, there are also species more indicative of northern boreal, tree-line and tundra environments including, Dyschirius nigricornis, Elaphrus lapponicus, Helophorus arcticus and Olophrum boreale. Coleoptera suggest a considerable temperature gradient that allowed $H$. arcticus to survive in central New Brunswick several hundred years after its last record in Nova Scotia (Miller, 1995, 1997a). By 11,500 years ago all sites in Nova Scotia, including the three new sites described here, suggest mean July temperatures of 14 to $18^{\circ} \mathrm{C}$ while at Todd Mountain, Coleoptera suggest 9 to $12^{\circ} \mathrm{C}$. Using palynological and chironomid evidence, Levesque $e t$ al. (1997) have described, and accurately quantified, a steep climatic gradient of at least $9^{\circ} \mathrm{C}$ during the late-glacial from central New Brunswick south to Maine.

Coleoptera assemblages from Benacadie (4), Amaguadees (Miller, 1997a), West Mabou (Miller, 1996) and Sand Cove, New Brunswick (Miller, 1997b) that are younger than 10,800 years B.P., include the staphylinid Olophrum boreale. This has been interpreted as an indication of the expansion of a more northern boreo-montane assemblage becoming evident during the Younger Dryas. Even though the appearance of the " $O$. boreale assemblage" may not provide clear evidence of a drop in temperature, its appearance signals some change in the environment that includes temperature and a response to a change in vegetation cover. At both Amaguadees and Benacadie (4), (Miller, 1997a) and perhaps at West Mabou (Miller 1996), appearance of the "O. boreale assemblage" may lag the onset of the Younger Dryas. Dates at Amaguadees and Benacadie (4) suggest the greatest numbers of $O$. boreale are found sometime between 10,800 and 10,400 years B.P., suggesting beetles did not respond immediately to deteriorating climate, but gradually changed during the Younger Dryas event. The eurythermic species living in the Maritimes may have been able to adapt, at least for a time, to the deteriorating climate. The possibility exists that the date of 10,400 years B.P. at Amaguadees may be too young, and is a result of modern root contamination (Miller, 1997a).

At Blomidon, samples possibly as young as 10,600 years B.P. contain bark beetles, indicating the presence of trees following the onset of Younger Dryas cooling. For some reason the " $O$. boreale assemblage" identified at other sites has not been found at Blomidon. Perhaps these "colder" beetle species are not seen in sites farther from glaciers on Cape Breton Island (Stea and Mott, 1989) or in southern New Brunswick. Lismore also shows no indication of an " $O$. boreale assemblage" (Miller and Morgan, 1991). During the 12,000 to 10,800 years B.P. interval, Olophrum boreale and species sometimes occurring on modern coastal tundra may have 
been more numerous in the highlands of Cape Breton or in central New Brunswick near Todd Mountain. During the Younger Dryas they may have expanded locally to be recorded in fossil deposits on Cape Breton and in southern New Brunswick, but not at Blomidon or Lismore.

\section{ACKNOWLedGements}

Thanks to R. Stea and R. Mott for access to information and identifying field sites, T. Fletcher for fieldwork, C. Clayton for technical assistance, A.V. Morgan for access to University of Waterloo Quaternary Entomology Laboratory collections, and the Canadian National Collection-Coleoptera staff of Agriculture Canada. This work was supported by National Geographic Society Research Grant 4588-91.

Bright, D.E. 1976. The Insects and Arachnids of Canada, Part 2. The Bark Beetles of Canada and Alaska. Coleoptera: Scolytidae. Agriculture Canada, Research Branch Publication, 1576, 241 p.

Campbell, J.M. 1963. New World Micropeplinae. Canadian Entomologist, 100, pp. 225-267.

....- 1983. A revision of the North American Omaliinae (Coleoptera: Staphylinidae), the genus Olophrum Erichson. Canadian Entomologist, 115, pp. 577-622.

EliAS, S.A. 1994. Quaternary Insects and Their Environments. Smithsonian Institution Press, Washington, 284 p.

Goulet, H. 1983. The genera of Holarctic Elaphrini and species of Elaphrus Fabricius (Coleoptera: Carabidae): classification, phylogeny and zoogeography. Quaestiones Entomologicae, 19, pp. $219-482$

Levesque, A.J., Cwynar, L.C., and Walker, I.R. 1997. Exceptionally steep north-south gradients in lake temperatures during the last deglaciation. Nature, 385, pp. 423-426.

Lindroth, C.H. 1969. The ground beetles of Canada and Alaska, 6. Opuscula Entomologica Supplementum, 34, pp. 945-1192.

MAYLE, F.E. and CWYNAR, L.C. 1995. Impact of the Younger Dryas cooling event upon lowland vegetation of Maritime Canada. Ecological Monographs, 65, pp. 129-154.

Mayle, F.E., Levesque, A.J., and Cwynar, L.C. 1993 a. Accelerator-mass-spectrometer ages for the Younger Dryas event in Atlantic Canada. Quaternary Research, 39, pp. 355-360.

---- 1993b. Alnus as an indicator taxon of the Younger Dryas cooling in eastern North America. Quaternary Science Reviews, 12 , pp. 295-305.

McNeely, R. 1989. Geological Survey of Canada Radiocarbon Dates XXVIII. Geological Survey of Canada, Paper 88-7, $93 \mathrm{p}$.

MCNeely, R. and McCuaig, S. 1991. Geological Survey of Canada Radiocarbon Dates XXIX. Geological Survey of Canada, Paper 89-7, 134 p.

Miller, R.F. 1992. Coleoptera Fossils of Late-Glacial / Younger Dryas Age in Eastern Canada. Program with Abstracts, Geological
Association of Canada-Mineralogical Association of Canada, Joint Annual Meeting, Wolfville 1992, p. A79.

---- 1995. Late-glacial Coleoptera and the paleoclimate at Hirtles, Nova Scotia. Atlantic Geology, 31, pp. 95-101.

....- 1996. Allerod-Younger Dryas Coleoptera from western Cape Breton Island, Nova Scotia, Canada. Canadian Journal of Earth Sciences, 33, pp. 33-41.

---- 1997a. Late-glacial (Allered-Younger Dryas) Coleoptera from central Cape Breton Island, Nova Scotia, Canada. Canadian Journal of Earth Sciences, 34, pp. 247-259.

-.--- 1997b. Late-glacial Coleoptera in Maritime Canada and the transition to the Younger Dryas chronozone. Quaternary Proceedings No. 5, pp. 177-184.

Miller, R.F. and Morgan, A.V. 1991. Late-glacial Coleoptera fauna from Lismore, Nova Scotia. Atlantic Geology, 27, pp. 193-197.

Morgan, A.V., Morgan, A., Ashworth, A.C., and Matthews, J.V., Jr. 1984. Late Wisconsin Fossil Beetles in North America. In Late Quaternary Environments of the United States, Volume 1, The Late Pleistocene. Edited by S.C. Porter. Longman, London, pp. 354-363.

MotT, R.J. 1985. Late-glacial climatic change in the Maritime Provinces. In Climatic Change in Canada 5: Critical Periods in the Quaternary Climatic History of Northern North America. Edited by C.R. Harington. Syllogeus, 55, pp. 281-300.

....- 1994. Wisconsinan Late-glacial environmental change in Nova Scotia: a regional synthesis. Journal of Quaternary Science, 9, pp. 155-160.

Mott, R.J. and SteA, R.R. 1993. Late-glacial (Allerod-Younger Dryas) buried organic deposits, Nova Scotia, Canada. Quaternary Science Reviews, 12, pp. 645-657.

Mott, R.J., Grant, D.R., Stea, R.R., and Occhietti, S. 1986a. Late-glacial climatic oscillation in Atlantic Canada equivalent to the Allerod-Younger Dryas event. Nature, 323, pp. 247-250.

Mott, R.J., Matthews, J.V., JR., Grant, D.R., and Beke, G.J. 1986b. A late glacial buried organic profile near Brookside, Nova Scotia. Current Research, Part B, Geological Survey of Canada, Paper 86-1B, pp. 289-294.

Schwert, D.P., Anderson, T.W., Morgan, A., Morgan, A.V., and KARROW, P.F. 1985. Changes in Late Quaternary vegetation and insect communities in southwestern Ontario. Quaternary Research, 23, pp. 205-226.

SteA, R.R. and Mott, R.J. 1989. Deglaciation environments and evidence for glaciers of Younger Dryas age in Nova Scotia, Canada. Boreas, 18, pp. 169-187.

Stea, R.R., Conley, H., and Brown, Y. 1992. Surficial Geology of the province of Nova Scotia. Nova Scotia Department of Natural Resources, Map 92-3, Scale 1: 500,000.

W ALKER, I.R., MotT, R.J., and SMOL, J.P. 1991. Allered-Younger Dryas lake temperatures from midge fossils in Atlantic Canada. Science, 253, pp. 1010-1012.

Wilson, S.E., Walker, I.R., Mott, R.J., and SMOl, J.P. 1993 Climatic and limnological changes associated with the Younger Dryas in Atlantic Canada. Climate Dynamics, 8, pp. 177-187. 